\title{
Beyond Drama: Postdramatic theater in upper level, performance-oriented foreign language, literature and culture courses
}

\author{
Morgan Koerner
}

\begin{abstract}
This article makes the case for expanding drama pedagogy in foreign language education to include strategies from postdramatic theater, which abandons traditional notions of plot, character, and dialogue and prioritizes theatrical performances over dramatic texts. The article presents findings from an action research project conducted with undergraduate students of German at the College of Charleston, South Carolina in the spring semester of 2013. It describes and discusses the efficacy of specific postdramatic theater strategies and assignments that encouraged Bachelor's students of German to think beyond dramatic convention by detaching body from character, separating voice and movement from text, and exploring a heterogeneity of theatrical codes via hands-on writing and directing exercises. Based on extensive documentation of the course and the learners' experiences, the article concludes by discussing postdramatic theater's capacity to promote foreign language learning, critical thinking, and unfamiliar modes of perception and signification.
\end{abstract}

\section{Introduction: Performative Foreign Language Didactics and Postdramatic Theater}

According to Manfred Schewe's recent overview of the field, drama pedagogy in foreign language (FL) education is now transforming into a "Performative Foreign Language Didactics," a more inclusive and open model that "actively seek[s] dialogue and exchange with the arts, in particular with theatre arts and also school/university subjects related to the aesthetic field" (2013, Section 5, Paragraph 3). This shift heralds an expansion beyond traditional drama-based methodologies and towards the broader possibilities offered by the medium of theater and by the creative arts. Yet the current landscape in performanceoriented FL teaching and research continues to be dominated by the literary genre of drama and by identification and role-play exercises. ${ }^{1}$

\footnotetext{
${ }^{1}$ A survey of seminal works on drama and theater in foreign language education reveals an emphasis on plot and character psychology (cf. Schewe, 1993; Kao and O’Neill 1998; Tselikas
} 
The unremitting focus on plot and character is understandable: the traditional toolkit of drama pedagogy boasts a long list of well-documented benefits for foreign language learning from beginning to advanced levels, benefits that I have witnessed time and again as a university professor of German as a Foreign Language in the United States. ${ }^{2}$ With these benefits, however, come limitations: The generic category implied by the very name drama pedagogy might restrict practitioners insofar as it implies the prioritization of drama. In other words, the emphasis on the literary genre of drama and its primary categories of character, plot, and dialogue neglects other theater forms that have tremendous potential for pedagogical implementation in foreign language classes. The following article describes my attempt to explore the advantages and disadvantages of a theater beyond drama in a performance-oriented FL language course on postdramatic theater. Specifically, I discuss the efficacy of postdramatic theater strategies and of assignments that engage students actively as actors, authors, and directors. Based on extensive documentation of the course and the learners' experiences, I consider the extent to which postdramatic theater fosters linguistic development, student engagement and autonomy, reflection on perception and meaning-making, and critical encounters with FL cultures, literature, and media.

\section{Postdramatic Theater: What is it and what might it be good for in FL Courses?}

German theater scholar Hans-Thies Lehmann coined the term postdramatic theater in his 1999 monograph of the same name to describe theater performances that transcend traditional dramatic categories and prioritize the performance over the dramatic text. In the wake of a larger "performative turn" in the arts that occurred internationally in the 1960s (Fischer-Lichte 2004), many European theater authors and practitioners have departed from traditional dramatic categories such as plot, character, and dialogue, and have instead prioritized other theatrical sign systems. In postdramatic theater, performance-specific considerations such as space, time, and the actors' bodies

1999; Even, 2003; Kessler 2008). Even drama pedagogy's emphasis on tableaux or Standbilder, which could easily be used in allegorical, experimental, and postdramatic theater traditions, is normally oriented towards exploring character psychology and plot (cf. Even 2008, Jäger 2011). Recent publications have highlighted the potential of Theaterwissenschaft (Küppers et. al, 2011, 8), performativity (Schewe 2011, 2013), and even postdramatic theater (Sting 2012), but an explicit study of postdramatic strategies in FL teaching has yet to appear. To my knowledge, Les Essif (2006) comes the closest: although he does not use the term postdramatic, his performance-oriented French seminars explore theater semiotics and experimental theater traditions and thereby push the boundaries of dramatic convention and emphasize the primacy of theatrical performance over dramatic text.

${ }^{2}$ As someone trained in Literary Studies, I have been particularly intrigued by how identification exercises and role play scenarios can catalyze interest in literature among a generation who have little experience reading literary texts, or reading anything for that matter, even in their native language. 
and voices gain equal footing with the dramatic text, and theater becomes more difficult to distinguish from non-textual performance art and dance (Lehmann 1999: 241-243). In this context, the term "theater text" more accurately describes the works written for the theater than does "drama," as more and more authors abandon the categories of drama and cede an increasing amount of control to the directors and actors, whose performances are prioritized (cf. Poschmann 1997).

Postdramatic theater, according to Lehmann, counters the dominance of cinema, television, and the entertainment industry, which have coopted "drama" in its simulation of psychological characters and engaging plotlines (Lehmann 1999: 22-3, 409). In response to the usurpation of drama by televisual media, theater authors and practitioners began to experiment with and explore other modes of representation and perception, of thought and signification beyond the confines of dramatic convention.

In the context of foreign language learning, postdramatic theater strategies have the potential to enhance the pleasure of playful, kinetic experimentation that can be found in drama pedagogy, expose students to unfamiliar ways of perception and signification, and engage students in the active production of meaning, not only as actors but also as directors. Moreover, with its rejection of plot and character psychology, postdramatic theater provides a space for critical reflection about the omnipresent dramatic narratives in contemporary media.

\section{Beyond Drama: A German Course at the College of Charleston for German majors/minors at the B1-C1 proficiency levels.}

It was with the above potential benefits in mind that I set out to teach a performance-oriented German course on postdramatic theater at the College of Charleston in South Carolina in the spring of 2013. The 14-week course, which was conducted entirely in German and met twice a week for 75 minutes, explored $20^{\text {th }}$ century German theater traditions that depart from traditional drama. The course began with Epic Theater, moved on to Dadaist and Neo-Avant-Garde performance, and then concluded with postdramatic theater texts and performances. Over the first 10 weeks, we explored these different examples via acting, creative writing, and directing exercises. During the final 4 weeks, the class revisited previous assignments in order to create scenes for a final, public class performance in German entitled "Beyond Drama: 13 performers try to transform the audience." The participants, who received a grade and credit for the course, submitted reading and creative writing assignments throughout the first 10 weeks, and then split into groups that wrote and/or directed scenes for the final, public performance. ${ }^{3}$

The 13 "performers" in my course were undergraduate majors and minors in German. Although the course was offered as an upper level seminar, the

\footnotetext{
${ }^{3}$ Here I followed a course model that I discuss at length elsewhere (Koerner 2012).
} 

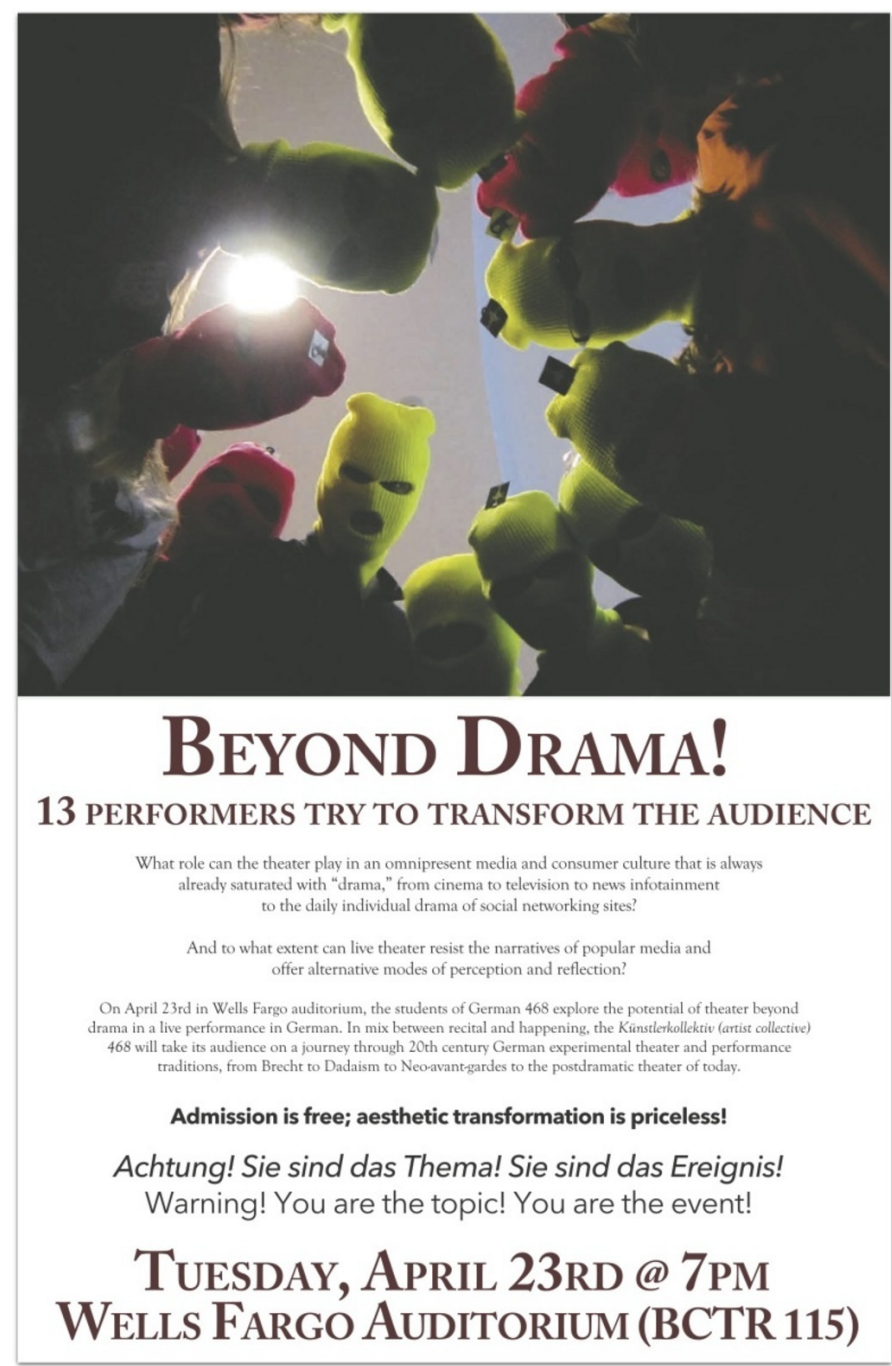

Figure 1: Advertisement for the Final Performance

participants came into the class with a wide range of language proficiencies, from the B1 level to the C1 level of the Common European Framework of Reference for Languages (the majority of the class was at or near the B2 level). In terms of the course content, only three of the thirteen students had any practical experience with or knowledge about theater, and only one was familiar with experimental theater traditions from the $20^{\text {th }}$ century. Consequently, the vast majority of the class was completely unfamiliar with thinking outsides of the traditional confines of character psychology and plot when approaching drama and theater.

The course topic thus posed a set of difficult pedagogical questions: how does one introduce US-American students to experimental and postdramatic theater traditions without access to the theater offerings of a major European city? And how does one do so with a group of students with a wide range of language 
proficiencies and little to no experience with theater, much less experimental theater? From the very beginning, I opted for a hands-on, inductive exploration of theater semiotics and specific postdramatic theater strategies. The goal was to facilitate an experience of postdramatic theater aesthetics from the perspective of actors, audience members, and-later on-directors. Through repeated acting and then directing exercises, students were sensitized to postdramatic aesthetic strategies while we moved through the more familiar methods of Epic Theater to the insanity of Dadaism to the performative turn of the 1960s and postdramatic theater.

\section{Postdramatic Acting and Directing Exercises}

\subsection{Detaching Body from Character}

The body in postdramatic theater no longer primarily serves meaning, messages, or mimetic representation, but rather is employed in order to emphasize physical presence and its effects on the audience (Lehmann 1999: 366-70). In order to encourage this insight experientially and introduce students to the semiotic building blocks of theater, I adopted and adapted acting warm-ups from an approach outlined by Maike Plath, a theater teacher at a vocational school in Berlin $(2009,2011)$. In the first ten minutes of almost every session, I split up the class into two groups to take turns performing an ever-growing repertoire of theater signs. The first day focused on simple kinetic and gestural signs: I asked the groups to walk around the room at different paces (on a scale of 1 to 10), and then called out a handful of directions: "freeze," "slowly turn your head to the audience," "blow a kiss to the audience," "wave to the audience." In subsequent class sessions, we revisited the exercises and, with each new warm-up session, added to our expressive repertoire: on the second day, we added several mimic signs (or facial expressions), including "critical," "in love," "joyful," and "sad," and the groups were able to witness the effects of conflicting facial expressions and gestures, such as "freeze and wave to the audience with a critical face." Thereafter, we added directions involving proxemics signs, i.e. the placement of the actors on stage, such as different spatial formations, the call to assemble into a "group photo," or spontaneous tableaux. As the semester continued, we expanded our list of directions and I provided updated versions via handouts.

The exercises served several functions: they allowed the group to focus their energies at the beginning of class; they sensitized participants to physical acting and made them more comfortable acting in front of an audience; and they introduced the participants both as doers and viewers to the aesthetic building blocks of physical theater. But the daily warm-up exercises had a further purpose, namely: to introduce the participant to acting and directing beyond the telos of character and plot. As we increased our repertoire of gestures and movements, I began to ask students in the audience to take over as directors and call out the directions to the class while watching the effects they generated. 


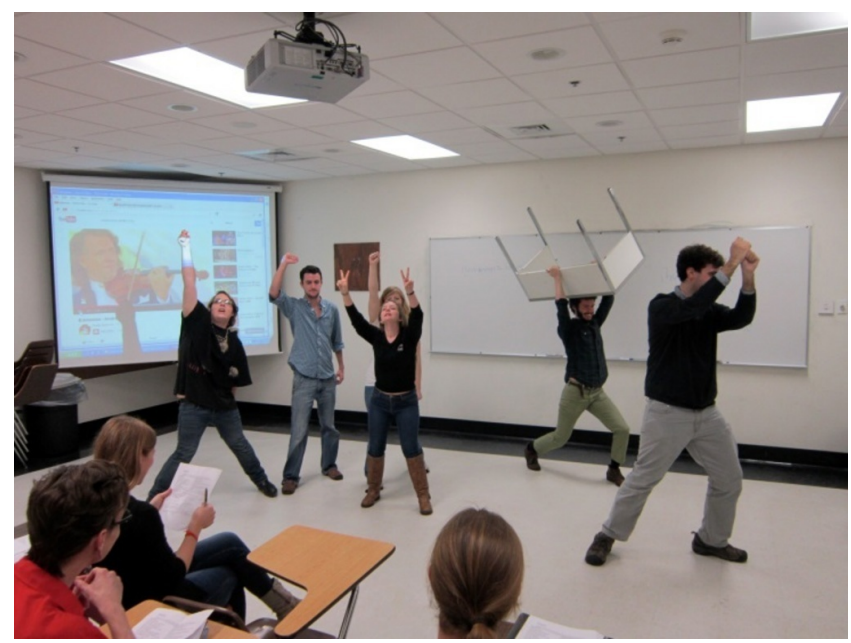

Figure 2: Student directing during an acting warm-up (tableau: revolution!)

The daily experiences with non-identification oriented performance prepared the course participants for their first encounter with a truly postdramatic theater text, Peter Handke's Publikumsbeschimpfung (Offending the Audience) (1966). Handke's so-called "speak-in" consists of a 40-page-long direct address of the audience, originally presented by four different actors. While the text challenges the audience to reflect on their own position as viewers instead of immersing in an illusion, it also poses a challenge for the theater insofar as its realization-there are no stage directions, only text. When we initially read the text, everyone in class was at a loss for how to imagine it until we revisited their theater-semiotics training via a group directing assignment. I split the class into 3 groups and gave each an excerpt from the play; each group then divided the text among speakers in their group; then each group member prepared a staging for a specific part of their excerpt. On the next day of class, the groups then directed each other, rehearsed, and then presented their stagings. The theater warm-ups provided the group with a basic set of aesthetic building blocks that they could use to experience the performativity of Handke's text, but they also provided the groups with a framework for adding new gestures and movements to their staging. In the end, the assignment highlighted the creative, dynamic thinking that postdramatic theater demands from its actors, directors, and audiences.

\subsection{Detaching Voice and Movement from Language}

Whereas traditional dramatic theater prioritizes dialogue and language, postdramatic theater stages the conflict between body and word, between voice/movement and language. In terms of spoken language, paralinguistic signs such as rhythm, volume, tonality, and various vocal distortions emphasize the materiality of language and the performative dimension of the text, the speech act as an event (Lehmann 1999: 269-70; Schrödl 2009: 174). 
The detachment of voice from content, like the unconnected gestures and movements in our acting warm-ups, is alien to most students and requires significant sensitization. I gradually, inductively introduced the ensemble to the notion of detaching voice from speech via spoken warm-up exercises. In the section on Epic Theater, for example, I included a warm-up exercise in which students read a poem from Brecht ("Erinnerung an die Marie A") in a series of different voices and rhythms that did not correspond to the text, such as "cheesy entertainer," very high, very low, Batman, singing, etc. We expanded on and continued to practice different, increasingly bizarre ways of reciting lines and when we reached Handke's text, participants were required to choose a passage and read it in two different voices that sounded nothing like themselves. The voice recording assignment emphasized the performativity of the text and the creative, active decision making it demands from its actors/directors.

By the time we reached contemporary theater texts, the participants were well prepared to explore postdramatic theater and to experience the collaborative, communal and experiential aspects that are so often ignored in literary and even performance analysis. Our exploration of German author-director René Pollesch's theater exemplified the advantage of the performative approach. Pollesch's renowned theater work exemplifies the prioritization of performance over text in postdramatic theater. His theater texts forego clear characters or plots, contain associative rants consisting of theoretical citations, pop cultural references, and juvenile vulgarity, and are inseparable from their stagings. ${ }^{4}$ In the early to mid 2000s, Pollesch's theater performances usually consisted of 3-5 actors seated on stage who rapidly spoke his text in a staccato style reminiscent of television news announcers. The speech was only interrupted when the actors screamed passages signaled with all capital letters and during "clip sequences," moments when the actors took a break from speaking and performed associative and often nonsensical pantomimes to popular music (Kassay-Schuster 2012: 83-6). The actors' speaking style emphasized the materiality of language and the physical bodies of the actors over the content, and the clip sequences detached movement and gesture from the language of the text (the actors remained seated when speaking and only gesticulated when screaming). When we covered the first episode of Pollesch's 2001 series $w w w$-slums, we watched several video examples of Pollesch's theater and began to work on mimicking Pollesch's strategies. Students were later divided into groups of four and tasked to prepare a segment for the next class session, including two "clip sequences" as an intro and outro to their scene. The participants presented their stagings and after the performances, they noted that they had a much better understanding of Pollesch's theater strategies than after their initial reading.

\footnotetext{
${ }^{4}$ Underscoring this point, Pollesch does not allow his works to be staged by anyone else because they are bounded to a specific space and team of collaborating actors.
} 


\subsection{Heterogeneity and Simultaneity of Theater Codes: Postdramatic Director's Theater}

By the end of the first ten weeks, we had developed our aesthetic repertoire enough to experience the heterogeneity and simultaneity of multiple theatrical codes and the semiotic excess common in some strands of postdramatic theater (Lehmann 1999: 149-150, 154-5). The class was thus poised to experiment with postdramatic director's theater, in which the director changes, adds to, comments on, deconstructs, multiplies, or otherwise creatively transforms the original theater text in performance. In order to explore the critical potential of such strategies, I chose a theater text from the Nobel prize winning Austrian author Elfriede Jelinek: Der Tod und das Mädchen II: Dornröschen (Death and the Maiden II: Sleeping Beauty). Jelinek's theater pieces, when they contain characters at all, present clichés and types instead of psychological figures, and they incessantly play with language and expose the absurdity and power of societal myths. Her texts' length, literary and linguistic density and minimal stage directions have challenged the stars of German director's theater to create spectacular multimedial productions of her works, and Jelinek has encouraged her directors to take liberties, to change and cut her texts, and to incorporate additional associations and reactions when staging them. She emphasizes the primacy of theatrical realization common to postdramatic theater and has thereby promoted a great deal of theatrical innovation on German speaking stages. The text I chose to explore in our class, Jelinek's take on Dornröschen (Sleeping Beauty), offers a specific critique of gender clichés as propagated in fairy tales but also in contemporary media. It consists of a fragmented dialogue between a princess and a prince who has evidently just kissed her back to life. Around this superficial dramatic situation, the language is associative, fragmented and monological and there are minimal stage directions. The play's short length of ten pages, its familiar cultural reference, and its topical theme of gender relations and media representation gave students a manageable framework for exploring postdramatic directing's critical potential.

The three days spent on Dornröschen encouraged the group to respond to the text as experimental directors. On the first day of the teaching unit, I demonstrated a host of directorial strategies via video clips from performances, including the detachment of gesture and voice from language, the use of a heterogeneity of theatrical signs, semiotic excess, the multiplication of roles, abstract movement, and associative, non-linear imagery. As an assignment for the second day, students read Jelinek's text and wrote down passages from the language under the following thematic rubrics: feminine identity, masculine identity, the media, and death/the passing of time. On the beginning of the second day, the class used their passages to experiment with the detachment of voice from language: they recited their citations in different voices (differing paralinguistic signs) in groups. Then, we attached abstract associative movements and gestures to their passages: groups brainstormed an accompanying gesture for one of their citations. We subsequently returned 
to our usual acting/directing warm-up, but this time integrated everyone's gestures. In discussion, we then reflected on the connections between the play's themes and satirical impetus and the students' gestures. The capstone to our consideration of Jelinek involved a multimedial directorial assignment due on the third day. I tasked students to create a voice recording of a passage or a collage of citations in two different voices and provide an image that they associated with the text. After posting their voice recording, they were required to compose directions for a choreographed sequence with three female and three male actors ( 3 princes and 3 princesses) that would be performed simultaneously with their voice-over recording, a projection of the image they associated with the text, and a song or soundscape of their choosing. In the following class session, each student presented their multimedial interpretation of Jelinek's text by directing others from the class. Over the 75 minute session, we witnessed a wide range of critical reflections on Jelinek's text. Each student was able to employ a wide range of theatrical signs in an interpretation that emphasized neither character nor plot, but rather the theater as a canvas for representation and reflection beyond drama.

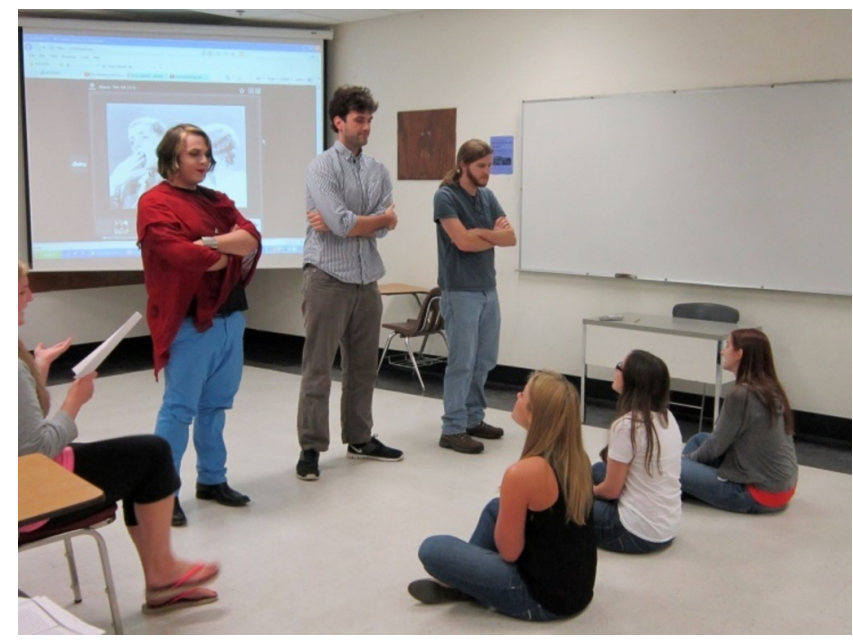

Figure 3: Student directing presentation on Dornröschen

The final performance included a variety of scenes created by the course participants. A particularly successful group revisited the Jelinek exercise and created a multimedial production involving the entire class. Moreover, the students improved upon my assignment by splitting up responsibilities: one rearranged the text into a short script, another created a collage of citations from Jelinek to be read from disembodied voices on microphones, and the third created a video mash-up that images from Disney princess films together with violent action and horror movie images and normative media portrayals of female beauty, all to the tune of Nina Hagen and Apocalyptica's song "Seemann." The result of the collaboration was a spectacular and powerful scene in our final performance that multiplied and localized Jelinek's critique of gender clichés in the media. 


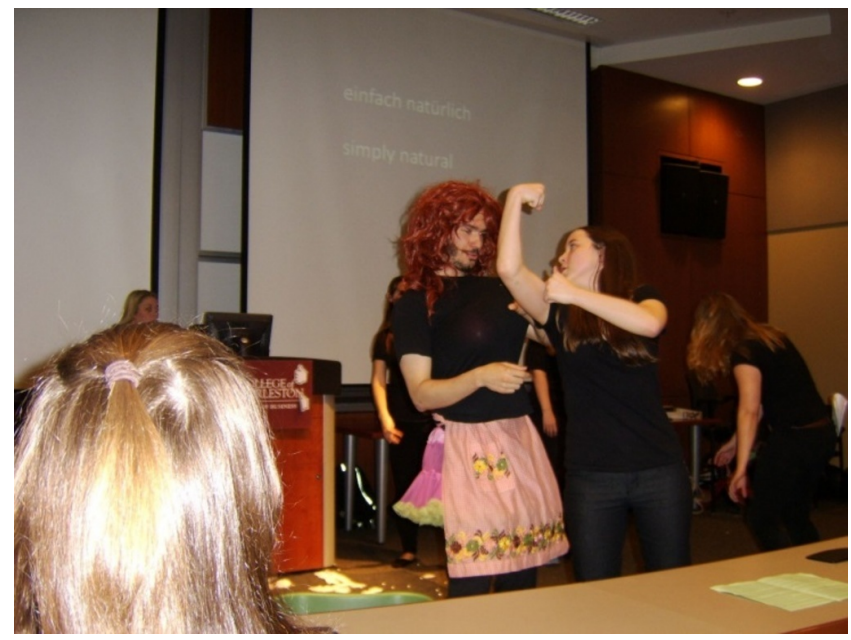

Figure 4: The group's Dornröschen staging in the final performance

\section{After Beyond Drama: Results and Insights}

After the conclusion of the course, twelve of the thirteen participants took an anonymous survey. Students evaluated nineteen statements on an adapted Likert scale of 1 to 10, (with 1 indicating strongly disagree, 10 strongly agree, and 5 neutral), and then answered 12 open-ended response questions. The following summarizes the student responses in relation to my hypotheses about postdramatic theater's potential for upper-level FL courses.

\subsection{Student Engagement and Learner Autonomy}

As in more traditional project-oriented theater classes I have taught, student engagement and enjoyment of the course were very high. $91 \%$ of the students surveyed (11 out of 12) agreed that the course engaged them as an active learner, and $66 \%$ (8 out of 12 ) strongly agreed. On the question "How has your role as a learner in this course been different than in other literature and culture courses?", the answers underscored both engagement and learner autonomy, and several students commented on their active and self-determined role as course participants:

It has been incredible, the actually getting up and doing these techniques has been so much more memorable than just getting lectured on them. [. . . ] Acting it out sticks with me better. It's way more engaging than any other course.

It was a different approach to effectively concern myself with the "final" [i.e. the final performance] from day 1 . Homework and exercises that I might have felt had little purpose were more meaningful.

It forced a more active participation with the text, rather than a passive, dead inhalation of required readings. 
In literature and culture courses, the instructor is almost always the leader. However, I feel that many of us, including me, were thrust into varying roles of leadership. Especially when we acted as directors or when we developed our roles for the final performance. I felt we were in charge of the production.

My own experience of the course matched the student responses. I can honestly say that I have never taught a project-oriented theater class in which the group had as much control of the final performance, and this student ownership suggests a benefit of postdramatic theater. While it is certainly possible to engage in autonomous learning via more traditional, dramatic theater techniques, the open-ended nature of postdramatic theater texts, combined with the collaborative hands-on approach and emphasis on student decision-making, encouraged leadership, responsibility, and independence among the participants.

\subsection{Linguistic Development/Improvement}

The student responses on their linguistic development in the course were also strong, although slightly less so than the responses on engagement and autonomy. ${ }^{5}$. The course was a senior, $4^{\text {th }}$ year level seminar and addressed at the $\mathrm{B} 2$ to $\mathrm{C} 1$ levels, but due to the nature of our program, many majors and minors take coursework out of sequence and the proficiencies thus ranged from B1 to C1. Because of the wide range of proficiency levels, I focused less explicitly on didacticizing assignments to promote specifically targeted language development than I have in other courses, and instead opted for individual feedback on writing and pronunciation. During in-class discussion and the exercises in plenum, however, it became clear that postdramatic theater may not be the ideal format for learners at the B1 level, where character identification, stock characters and plots, and improvisation games may be more beneficial because they provide a natural format for many of the emerging language abilities at the B1 level of the Common European Framework of Reference for Languages. ${ }^{6}$ The group decision-making, discussion, and playful exploration of complicated theater texts in the course demanded a higher set of

\footnotetext{
5 The responses to the statements on language learning were as follows. Note that with each question, 12 out of 13 students strongly agree while one remains neutral or disagrees: "This course has improved my spoken German." 8.41 average $(5 \times 10,3 \times 9,8,7,6,3)$; "This course has improved my ability to improvise when speaking German" 8.83 average (7X10, 3X9, $6,3)$; "This course has made me a more confident German speaker". 8.58 average (3X10, 6X9, $2 X 7,5)$; "This course has expanded my active vocabulary in German" 8.5 average (41percnt strongly agree, 9, 4X7, 2X6); "This course has improved my writing in German." 7.9 average (2X10, 4X9, 3X8, 2X6, 5); This course has improved my reading skills in German" 8.08 average $(2 \times 10,4 X 9,3 \times 8,6,5)$.

6 The global scale of the Common European Framework shows a clear difference between an independent language user at the B1 level, who can navigate personal and every day situations, and a user at the B2 level, who is able to participate and discuss and explain viewpoints on a wide range of subjects (Council of Europe 2001: p. 24).
} 
language abilities that extend beyond personal and towards the more abstract, or to put it in terms of the European Framework, towards the B2 and C1 levels.

\subsection{Critical Reflection and New Modes of Perception and Signification}

Regarding the goal of more abstract reflection, almost all of the students agreed that their experience with postdramatic theater made them more critical of dramatic narratives and the media and that the course also changed the way they think about theater and drama. ${ }^{7}$ The different responses to survey question Number 3, "To what extent has this course changed your perception of the theater?", demonstrate the shift in perspective that the course material and approach elicited in almost all of the participants:

Theater was combined to a toy box in my mind before this class, and now, the box is broken.

This course has allowed me to see theater as a vessel for commentary about the world. I also view theater as unique in that it is a live experience [. . . ] In many ways the theater is the least realistic medium but the most real.

This course has taught me to challenge what kind of entertainment is brought before me and ask questions instead of sit there watching like a dumb-founded vegetable.

There is so much more theater can do than acting as a form of entertainment. It can reflect on a culture or time period or get you to think critically / call you to action.

The artist uses the medium not only to make a statement, but to pose a question.

The written comments revealed a general shift in students' understanding of theater from an emphasis on plot and entertainment and towards theater as a site of critical engagement and questioning. Of the twelve students polled, only one seemed to have not gained any new perspective from the experience, as evident in the following suggestion at the end of the survey, namely that in the future, the course should "focus on effective, powerful acting (brilliant plots, intense dialogue) rather than silliness which looks ridiculous and has no meaning for a general audience." This statement came as a surprise because there was no open resistance to the material in the course, yet I view it as a massive success that only one student out of the entire group managed to resist revising their understanding of the theater. In a group of US-American

\footnotetext{
7 "This course has caused me to reflect critically on the media and my role as a media consumer" 7.8 average $(10 \mathrm{X} 5,2 \mathrm{X} 9,7,2 \mathrm{X} 6,5,2)$; “This course has made me more likely to question dramatic narratives and the construction of plot and character in drama." 8.5 average $(10 \times 6,9,2 \times 8,6,5)$.
} 
students with no experience with experimental theater, one might justly expect more naysayers than our one holdout. It is a testament to the hands-on, interactive approach of the course, I believe, that the vast majority underwent a transformative experience similar to another respondent, who noted that while the acting and directing assignments seemed "weird" at first, the material and the approach managed to catalyze a perspectival paradigm shift: "in a way, the fourth wall is broken not only in a theatrical sense but also in an intellectual sense. I felt more open." Postdramatic theater, when taught in an inductive, hands-on, experiential fashion that promotes student autonomy, clearly promotes critical reflection and opens up new modes of thinking and perception for millennial students.

\section{Postdramatic Pedagogy and Potential Performative Expansions in Foreign Language Didactics}

Postdramatic theater, as my experience of the course and my students' comments confirm, offers an important expansion of the methodological toolkit of drama pedagogy. Whether the approach should be combined with more traditional, dramatic methods or, as in my course, receive the primary focus, depends on the instructor's goals. In the context of language development, the reduced focus on improvisation "in role" poses a potential obstacle for learners at the B1 level and below. Indeed, because they are usually based on identification, stock characters, and plots, improvisation games and exercises proved difficult to integrate into a course that focused almost exclusively on experimental theater. Nevertheless, one of the most important insights that I have taken away from the experiment is that postdramatic theater does indeed allow for identification, albeit not with characters. As one student noted in the survey,

This course actually allowed me to see how German theater was created. I felt that I saw through the eyes of the artists in a way even though I may have disagreed with their ideas or messages. At the risk of sounding arrogant-I feel that I shared in their genius for a brief moment.

In other words, many of the creative writing and directing exercises demanded that the class identify with artists, authors, directors and artistic movements rather than with fictional characters. This sort of identification has tremendous potential for advanced language classes. Imagine, for example, improvisational games where students assume the role of an artist or intellectual in order to argue their opinions with others, attend an intellectual discussion at a coffee house, a vernissage, etc. Postdramatic theater and other experimental theater traditions might offer possibilities for a kind of meta-identification that also corresponds to higher-level linguistic tasks; paradoxically, they thus might offer a way to continue the pleasures of speaking "in role" in more linguistically and thematically complex contexts.

In terms of critical thinking and the exploration of literature, media, and culture, postdramatic theater has other clear advantages, especially for upper 
level performance-oriented foreign language courses. Whereas identification and role-play scenarios usually require a separate level of discussion, reflection and analysis, postdramatic directing and acting assignments come closer to integrating critical reflection into artistic process. They continue the playful, experiential approach common in drama pedagogy, but simultaneously integrate a level of distance and reflection about the construction of narratives. Future studies would do well to examine more closely the ways in which postdramatic theater strategies can be used to explore and question television, film, and digital media. Devised postdramatic theater work, as a response to examples from television and film, remains an unexplored yet very promising approach to foreign language and culture courses.

As drama pedagogy in FL education now branches out into a "Performative Foreign Language Didactics," we should be encouraged to continue to take risks and experiment with performative art forms in our courses, because our method, the approach of learning-by-doing with body and mind, gives us a better chance to reach millennial students and to introduce them to new modes of perception and thought. Further, there is much to be gained by expanding our purview beyond acting to include collaborative directorial work and student ownership of all aspects of the performance. Collaborative learning-by-doing-and-creating not only maximizes student engagement, it also catalyzes critical reflection on questions of representation and narrative.

\section{Bibliography}

Council of Europe (2001): The Common European Framework of Reference for Languages: Learning, teaching, assessment. Cambridge: Cambridge University Press

Essif, Les (2006): The French Play. Exploring Theatre "Re-creatively" with Foreign Language Students. Calgary: University of Calgary Press

Even, Susanne (2003): Dramagrammatik. Dramapädagogische Ansätze für den Grammatikunterricht Deutsch als Fremdsprache. München: iucidium

Even, Susanne. Moving in(to) Imaginary Worlds (2008): Drama Pedagogy for Foreign Language Teaching and Learning. Unterrichtspraxis / Teaching German 41/2, 161-170

Fischer-Lichte, Erika (2004): Ästhetik des Performativen. Frankfurt/Main: Suhrkamp

Jäger, Anja (2011): Improvisationen auf literarischer Grundlage zur Förderung von interkulturellen Kompetenzen. In: Almut Küppers/Torben Schmidt/Maik Walter (eds): Inszenierungen im Fremdsprachenunterricht: Grundlagen, Formen, Perspektiven. Hannover: Schroedel, 164-79 
Jelinek, Elfriede (2004): Der Tod und das Mädchen I-V. Berlin: Berlin Verlag Taschenbuch

Handke, Peter (1966): Publikumsbeschimpfung und andere Stücke. Frankfurt: Suhrkamp

Kao, Shin-Mei / O'Neill, Cecily (1998): Words into Worlds: Learning a Second Language Through Process Drama. Stamford, CT: Ablex Publishing

Kassay-Schuster, Henriette (2012): Politics, Play, and Profanation: René Pollesch's 24 Hours Are Not a Day. In: Theatre Annual: A Journal of Performance Studies 65, 77-97

Kessler, Benedikt (2008): Interkulturelle Dramapädagogik. Dramatische Arbeit als Vehikel des interkulturellen Lernens im Fremdsprachenunterricht. Frankfurt: Peter Lang

Koerner, Morgan (2012): German Literature and Culture under Revue: Learner Autonomy and Creativity through the Theme-Based Theater Practicum. In: Die Unterrichtspraxis / Teaching German, 45.1, 28-39

Küppers, Almut, Torben Schmidt and Maik Walter (2011): Inszenierungen - Present tense incarnate im Fremdsprachenunterricht. In: Küppers, Almut; Schmidt, Torben; Walter, Maik (eds): Inszenierungen im Fremdsprachenunterricht: Grundlagen, Formen, Perspektiven. Hannover: Schroedel, 5-17

Lehmann, Hans-Thies (1999): Postdramatisches Theater. Frankfurt: Verlag der Autoren

Plath, Maike (2009): Biographisches Theater in der Schule. Mit Jugendlichen inszenieren: Darstellendes Spiel in der Sekundarstufe. Weinheim: Beltz

Plath, Maike (2011): Freeze! \& Blick ins Publikum! Das Methoden-Repertoire für Darstellendes Spiel und Theaterunterricht. Beltz Verlag: Weinheim und Basel

Pollesch, René (2003): www-slums. Ed. Corinna Brocher. Berlin: rororo

Poschmann, Gerda (1997): Der nicht mehr dramatische Theatertext. Aktuelle Bühnenstücke und ihre dramaturgische Analyse. Tübingen: Niemeyer

Schewe, Manfred L. (1993): Fremdsprache inszenieren. Zur Fundierung einer dramapädagogischen Lehr- und Lernpraxis. Oldenburg: Didaktisches Zentrum, Universität Oldenburg 
Schewe, Manfred (2011): Die Welt auch im fremdsprachlichen Unterricht immer wieder neu verzaubern: Plädoyer für eine performative Lehrund Lernkultur! In: Küppers, Almut; Schmidt, Torben; Walter, Maik (eds): Inszenierungen im Fremdsprachenunterricht: Grundlagen, Formen, Perspektiven. Hannover: Schroedel. 20-31

Schewe, Manfred (2013): Taking Stock and Looking Ahead: Drama Pedagogy as a Gateway to a Performative Teaching and Learning Culture. In: Scenario $7 / 1$

Schrödl, Jenny (2009): Stimme und Emotion.Affektive Wirksamkeiten im postdramatischen Theater. In: Forum Modernes Theater 24/2, 169-82

Sting, Wolfgang (2012): Performance und Theater als anderes Sprechen. In: Scenario 6/1

Tselikas, Elektra I. (1999): Dramapädagogik im Sprachunterricht. Zürich: Orell Füssli 